\title{
Social Policy in Development: Coherence and Cooperation in the Real World
}

\author{
Merilee S. Grindle \\ CID Working Paper No. 203 \\ October 2010
}

(C) Copyright 2010 Merilee S. Grindle

and the President and Fellows of Harvard College

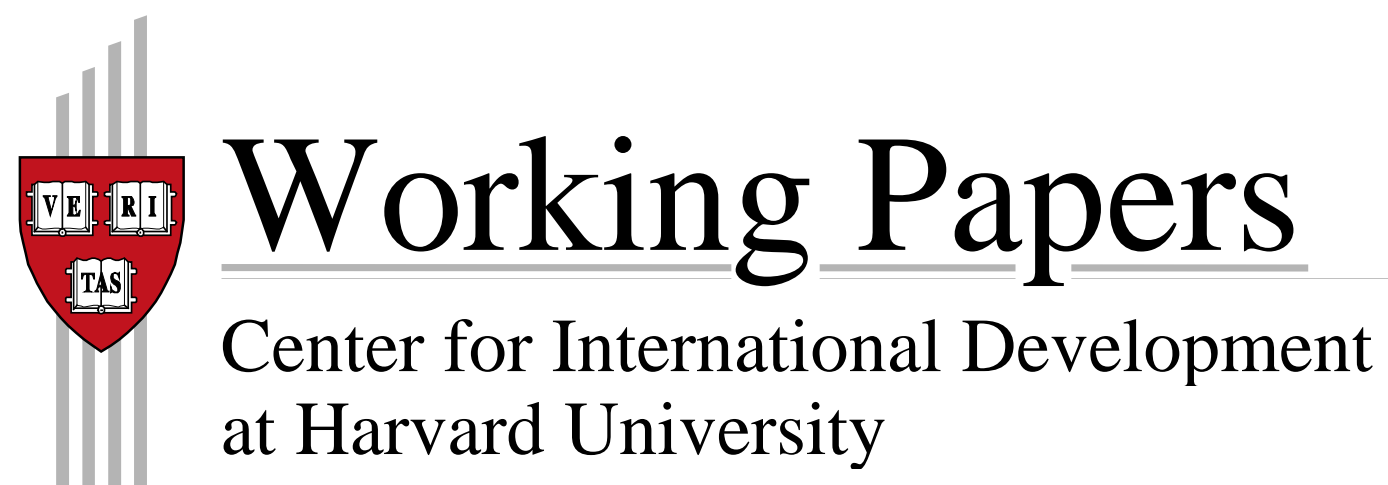




\title{
Social Policy in Development: Coherence and Cooperation in the Real World
}

\author{
Merilee S. Grindle
}

October, 2010

\begin{abstract}
Ideas about social policy and its role in development have shifted over time, signaling the difficulty of finding clarity in approaches to social investment, poverty alleviation, and equity. In consequence, research and practice related to social policy and poverty alleviation have left a legacy of a very broad agenda of "things that need to be done," along with important unanswered questions about how to integrate social and economic development. While these legacies contribute to the difficulty of developing overarching solutions to problems of social development and poverty alleviation, they also suggest the fruitfulness of focusing more on the distinctions among countries in terms of their capacities, generating ideas about priorities and sequences, and working to reduce what is often an overwhelming social policy agenda. The development community needs to get much better at matching ideas to realities, at considering how policy priorities could be assessed in terms of contextually specific feasibility, and at generating contextually grounded processes for taking the next step. While these are less ambitious questions than are often asked, they hold some promise of bringing ideas into better touch with the real world.
\end{abstract}




\section{Social Policy in Development: Coherence and Cooperation in the Real World Faculty Research Working Paper Series}

\section{Merilee Grindle}

Harvard Kennedy School

\section{J une 2010 RWP10-024}

The views expressed in the HKS Faculty Research Working Paper Series are those of the author(s) and do not necessarily reflect those of the John F. Kennedy School of Government or of Harvard University. Faculty Research Working Papers have not undergone formal review and approval. Such papers are included in this series to elicit feedback and to encourage debate on important public policy challenges. Copyright belongs to the author(s). Papers may be downloaded for personal use only. 


\title{
Social Policy in Development: Coherence and Cooperation in the Real World
}

\author{
Background Paper Prepared for \\ The World Economic and Social Survey 2010 \\ "Sliding Doors: Old and New Perspectives on \\ Social Policies and Economic Development"
}

\author{
Merilee S. Grindle \\ Edward S. Mason Professor of International Development \\ Kennedy School of Government \\ Director, David Rockefeller Center for Latin American Studies \\ Harvard University
}

January 2010

Multilateral development coordination and coherence are elusive goals. Diverse organizations in the international arena struggle to find common ideas on appropriate paths to development, common rules to shape interactions among countries, and common practices to assist governments in generating policies for economic and social development. Despite advances in each of these areas, development professionals, whether in the academy or in practice, have yet to find a focus or a structure that ensures that the ideas, rules, and policy advice lead to effective economic and social development. $^{1}$

In this paper focused on the role of social policy in economic development, I first indicate that the search for policy coordination and coherence must take into account the fact that ideas about social policy and its role in development have shifted over time, signaling the difficulty of finding clarity in approaches to social investment, poverty alleviation, and equity. Definitive responses to social provisioning, poverty, and inequality are likely to continue to be elusive; as such, it is important to sustain opportunities for debate, experimentation, innovation, and learning in considering approaches to social development. I suggest that finding ways to preserve these conditions, as well as to encourage deeper appreciation for the contextual factors that shape development outcomes, can be important contributions-however counterintuitive-of new forms of international coherence and cooperation.

In a second section of the paper, I indicate how research and practice related to social policy and poverty alleviation have left a legacy of a very broad agenda of "things that need to be done" for development to occur, along with important unanswered questions about how to integrate social and economic development. These legacies contribute to the difficulty of developing overarching solutions to problems of social development and poverty alleviation. At the same time, however, they suggest the fruitfulness of focusing more on the distinctions among countries in terms of their capacities, generating ideas about priorities and sequences, and working to reduce what is often an overwhelming agenda of things that need to be done. 
The third section of the paper provides a description of the political context within which social policy choices are made and signals some doubts about how much can be achieved at the level of specific countries through greater multilateral coherence and coordination. Choices about social policy and poverty alleviation engage a range of international and domestic actors with distinct interests and capacities to influence outcomes. The ability of international actors to influence domestic policy decisions varies as policies move from agendas, to decisions, to implementation. Ultimately, no matter what the degree of coherence and coordination, domestic politics constrain the best laid plans of international actors.

The concluding section of the paper provides an initial reframing of the issue of coherence and cooperation by suggesting a few questions of more limited scope. Instead of new big ideas and new paradigms about social development and poverty alleviation, I assert that the development community needs to get much better at matching ideas to realities, at considering how policy priorities could be assessed in terms of contextually specific feasibility, and at generating contextually grounded processes for taking the next step. While these are less ambitious questions than are often asked, they hold some promise of bringing ideas into better touch with the real world.

The analysis in this paper will not solve the problems of multilateral policy coherence and cooperation, nor will it resolve debates about the role of social policy in development. These limitations are disappointing, of course, but even at a time when researchers and practitioners are thinking expansively about the future of development, there is value in anchoring such discussions in a world of possibilities and probabilities, as well as in a world that we all can agree would be a much better one to live in.

\section{Ideas, Practice, and Crises: The Role of Social Policy in Development}

Since the end of the Second World War, researchers and practitioners have been engaged in a vibrant discussion of how third world nations become richer through a process of economic and social development. ${ }^{2}$ Moreover, each generation of development professionals tends to rediscover the links between social policy and economic development, but often in ways that alter the place of such policies in development. Thus, in some periods, social investment is deemed to be a necessary condition for economic development and at other times it is more likely to be seen as its consequence. Similarly, while social development is generally assumed to be a responsibility of the state, the kinds and extent of social provision thought to be appropriate for the state to undertake has varied across time. In addition, in some periods and in some perspectives, social policies are primarily focused on the problems of poor countries; at other times and in other perspectives, the primary issues of concern are the problems of poor people.

Expectations about the focus and consequences of social investments have thus varied over time in relation to ideas about how economic progress is achieved, the role of the state in development, and views on the primary function of such policies. These shifting ideas matter, for they have influenced development practice. They have, for example, led 
to altered priorities in national investment strategies, increased or decreased the range of social provision measures offered by states, and altered whether universal policies or targeted programs are the primary focus of public action.

The experience of putting ideas into practice has in turn generated revised thinking about how development is achieved and, over time, ideas and practice have interacted to expand, incrementally, the agenda of what needs to be done to ignite and sustain social development. In contrast, severe economic crisis has been responsible for a major paradigm shift in mainstream thinking and practice, but one that is now questioned; the agenda of what needs to be done has returned to an expansive mode. What follows is a stylized view of these shifting perspectives on the relationship of economic and social development, the role of the state in this relationship, and the primary focus of social policy_countries or people.

I.1. Early Perspectives on the State and its Role in Development. The field of development can be traced to the 1950s, when the emergence of a number of newly independent countries caught the attention of scholars and challenged them to develop theories about how economies grow, how social wellbeing is enhanced, and how stable political institutions develop. ${ }^{3}$ Relatively early, the emergent field of development economics became the lead discipline in defining the factors that were important for stimulating growth and wellbeing. ${ }^{4}$ Early views focused on stages or phases of development and grappled with the issue of the role of the state in advancing economic and social progress. Welfare maximizing states, for example, were considered appropriate vehicles for acting as accumulators and investors of capital to stimulate industrialization and to guide the use of capital in socially productive ways. Similarly, in the apparent absence of other sources of development, the state was thought to be well situated to act as an engine for development; growth would result from investments and incentives to stimulate industrialization and the expansion of modern agriculture. ${ }^{5}$ Central planning was considered an important means for increasing the effectiveness of state action and the allocation of resources, including resources for social development. ${ }^{6}$

It is important that the new discipline of development economics emerged in the mid-20 ${ }^{\text {th }}$ century, in a context of several decades of the expansion of the welfare state in industrial countries and the experience of active state intervention in their economies during the world depression of the 1930s and the Second World War. Keynesian economics and mid-century practice encouraged the expectation that in developing countries, governments should invest in human resource development as an important contributor to economic development. ${ }^{7}$ Given low levels of development that translated into conditions such as low literacy and high mortality, poor countries needed to invest in universal basic education, the provision basic public health infrastructure, and basic and universal health services focused on lengthening life expectancy and eradicating debilitating and endemic diseases. Such investments, it was affirmed, would stimulate and sustain economic development through the growth of productivity expected to result from a more skilled and healthy workforce. The purpose of these interventions was the general promotion of human capital development in poor countries, an emphasis that had become a significant part of mainstream thinking by the 1960 s. $^{8}$ 
In the 1950s and well into the 1960s, then, development economics promoted a significant role for the state in promoting social development as a condition necessary for growth. This important role for the state was echoed in the literature from political science, which emphasized the importance of nation building. Thus, strong and centralized states were seen as an important way to integrate often disparate societies and to create common sets of rules, habits of citizenship, and order. ${ }^{9}$ In early perspectives, the presence of one-party states, reformist military regimes, charismatic nationalist leaders, and authoritarian practices were at times viewed as conditions that were understandable in efforts to build stronger and more national states and bring order to divided societies.

That ideas played such an important role in these early days of focused attention on the nature of economic and political development is understandable; disciplines such as economics and political science had little data to draw from, other than the histories of already developed countries. Early discussion drew heavily on what was believed to have been the development experience of western countries. In addition, the post-World War II experience of rebuilding Europe, in which the Marshall Plan played a leading intellectual role, encouraged belief in the important role of international assistance in the development process.

I.2. Fractured Consensus and Agenda Expansion. As experience accumulated in the 1960s, however, the consensus on the relationship between social policy and development began to fracture. In particular, practice indicated that barriers to economic development, to "take off" in the words of some, were more complex than anticipated. Numerous structural factors reduced the efficiency of investments in industrial development, even while rapid advances were being made in social indicators such as life expectancy and literacy rates. The gradual accumulation of such data encouraged scholars to begin to view social development as a process that could advance regardless of economic growth and industrialization.

Moreover, in the aftermath of initial experiences observing the impact of ideas in practice, the agenda of what needed to be done to achieve economic and social development expanded significantly. In part, an expanded development agenda was the consequence of ideas being overtaken by events in the 1960s, as countries were forced to deal with a series of issues that loomed much larger than anticipated in earlier periods. In particular, the decade witnessed an unprecedented period of rural to urban migration; the beginnings of the growth of mega-cities in some countries; the fast-paced expansion of urban squatter settlements; initial concern about the capacity to generate enough jobs for new entrants into the labor pool, particularly in urban areas; and increased attention to the structural impediments to the development of small-holder agriculture in the tropics. Moreover, in politics, the 1960s witnessed significant expansion of mass-based political parties and competitive electoral politics in many countries around the world. Social mobilization and the ability of states to respond to increased social demands became issues of concern to development scholars and practitioners. ${ }^{10}$ 
These economic, social, and political perspectives encouraged agenda expansion. The provision of basic health and education continued to be considered a central responsibility of the state. At the same time, however, many increasingly argued that developing countries needed to address constraints on the productive capacity of peasant agriculture; invest more in the rapid expansion of public health infrastructure, particularly in urban areas; ensure the provision of urban housing and social protection for urban workers; address nutritional and social deficits that affected poor people; and attend to the imperative for job creation. ${ }^{11}$ In practice, policies to subsidize a wider range of social services were introduced to promote industrial, agricultural, and urban development. During the 1960s and 1970s, then, the range of activities undertaken by states to promote social development grew much wider, while their coherence across sectors and countries tended to wane.

Agenda expansion was also encouraged in this period by a shift in development thinking from how to deal with the problems of poor countries to the problems experienced by poor people. Initial observation of the impact of social development policies, as well as research on issues of equality and poverty, emphasized that developing country populations were differentially situated to take advantage of economic development and that they were differentially affected by development policy investments. Certainly, poor countries needed general investment in the provisioning of health and education, but poor countries also contained large numbers of poor people whose access to health and education services was constrained by where they lived and how they sustained themselves economically. Their capacity to benefit from development was limited by a series of conditions that could be responded to with specialized programs and interventions aimed at specific problems, and through alterations in the structures of power that limited their access to development. ${ }^{12}$

Thus, ideas about social policies expanded to take account of the particular needs and constraints that these poor people faced, needs and constraints that made it more difficult for them to benefit from growth and investments than better-off people. Issues such as agrarian reform, rural and urban development, basic needs including nutrition and shelter, low-income housing, and community development became important issues of discussion and action. As the social agenda expanded, the appropriate role of the state in social provisioning also expanded to incorporate many more activities and sectors. Social policy continued to be viewed as an ingredient to stimulate economic development, and at the same time to be separable from economic development as a valued end in itself. Moreover, it also became an important ingredient in discussions about how to avoid social and political instability. Similarly, countries that made significant advances in social development were thought to be investing wisely in the future potential for economic development.

At the same time that the social agenda expanded and became more multifaceted in addressing the constraints faced by poor populations in developing countries, discussions about what needed to be done to stimulate development became more fractured and contentious through the emergence and popularization of a radical critique of mainstream ideas. ${ }^{13}$ This critique emphasized that, due to economic and political conditions in the 
$20^{\text {th }}$ century, the development of new economies would be fundamentally distinct from that experienced by earlier developers; extrapolating from the history of European countries, scholars had ignored basic contextual differences between early and late developers. Instead, international trade relationships, colonialism and its aftermath, and the economic and political relationships between first and third world countries, as well as the distribution of economic and political power in the domestic politics of developing countries, indicated that basic power relationships had to be altered if third world countries were to be able to develop.

In order to progress, then, countries would have to break the constraints that led to underdevelopment — radical restructuring of ownership, for example, the conquest of political power, and the mobilization of societies to participate in their own development. Practice was important in reshaping these views - the Cuban Revolution, conflicts of the Cold War being fought out in Africa and Asia, and reflections on the "take off" of Japan were explained and incorporated into paradigms of development as part and parcel of conditions of underdevelopment. In this radical critique of mainstream theory, social development would be a consequence of altered power relations and would be a direct responsibility of a state committed to equality of conditions. While this critique was never appropriated into mainstream development discourse, it did encourage mainstream research to pay more attention to international constraints in development.

The expanded role for the state, the expanded social policy agenda, and the expansion of concerns about poor people and the constraints they faced in overcoming poverty continued to characterize development thinking in the 1970s. A considerable research agenda uncovered data about inequality and populations that were disadvantaged by development, in turn often adding to the agenda of what needed to be done to address poverty and powerlessness. ${ }^{14}$ Women, pastoralists, ethnic minorities, remote populations, slum dwellers, landless rural laborers, the urban underemployed—all became subject to discussions about inequity. ${ }^{15}$ In addition, due to research on the impact of exogenous shocks on poor populations-largely encouraged by the impact of the rapid rise in international oil prices_-scholars began to consider issues of the risks faced by poor people and the importance of policies that would cushion them against unanticipated shocks. Research on poverty similarly emphasized the vulnerability of poor people to the incidence of illness, environmental disasters, and economic changes that threaten livelihoods. ${ }^{16}$ Thus, the social development agenda was enriched by research and new insights at the same time that the signals about "what to do" became more complex and ambiguous.

I.3. Questioning the Role of the State. As these discussions continued, a neoclassical revival in economics began to be reflected in development economics by the mid 1970s. ${ }^{17}$ While in practice development continued to call for states to grow and to assume ever increasing roles in economic and social development, empirical evidence began to accumulate about the destructive capacity of states as engines of growth and providers of social development. Simultaneously, scholars focusing on political development in the mid and late 1970s became increasingly alarmed by evidence of the consequences of authoritarianism and centralization in the politics of many developing 
countries - corruption, brutality, military rule, and political repression took center stage in much political science focused on developing countries. ${ }^{18}$

Far from being engines of development and nation builders, then, states began to be viewed as a major constraint on development, with extensive intervention crippling opportunities for economic development and strong central states developing the capacity to repress authentic voices of citizens and their interests. ${ }^{19}$ For economists, a neoliberal revival began to see rent-seeking, corruption, and predatory states as the outcome of an excessive role assigned to the state in economic development. Political scientists fundamentally altered their earlier and more benign perspectives on military regimes, one-party states, and charismatic leadership. Regime transition and the consolidation of democracies emerged as major concerns in literature and conferences. ${ }^{20}$

These altered views had an impact on how social policies were viewed in terms of economic development. Now, greater attention was focused on the impact of social investment rather than on the needs for such investments. As part of an emerging critique of the role of the state in development, scholars and practitioners began to pay more attention to issues of how services were delivered, the extent to which their delivery was biased by corruption and clientelism, and the failures associated with ineffective or corrupt bureaucracies and their lack of capacity. The costs of social services, coupled with research on failures in delivering them effectively, fueled discussion of corruption, bias, and incompetence. The question of the positive role of social policy in development tended to fade in the face of this developing critique, even while development practice saw an increasing "projectization” of social policy interventions, in which a few national policies were joined by a large number of focused project interventions for specific purposes, the result of a continuously expanding agenda and expansion in development assistance.

I.4. Crisis and Paradigm Shift. This very significant shift in development thinking, with roots in the 1970s, became a mainstream paradigm quite quickly as a result of an international economic crisis in 1982. Massive debts of countries around the world and states floundering under their burden encouraged the promulgation and adoption of a series of radical policies to deregulate, liberalize, and downsize government. From a fractured view of what was needed to encourage development, the neoliberal era put economic growth clearly in the forefront of development objectives, stressing macroeconomic stability and fundamental structural change from state-dominated to market-oriented economies. ${ }^{21}$ In this new paradigm, markets rather than states were needed to ignite growth; previous emphasis on the role of the state was fundamentally flawed; social development was important, but could not be achieved in the absence of growth. Certainly for much of the 1980s, development thinking stressed that states were the problem, not in any way a solution, to generating growth and wellbeing. ${ }^{22}$

Moreover, the new paradigm was clear that failures to generate growth meant that states could not afford the extensive array of social policies and projects that had become common in the 1960s and 1970s. To deal with inflation, debt, and the fiscal crisis of the state, states needed to curtail their spending significantly, and spending for social 
development loomed very large in national budgets. Thus, a return to basics with a much more concerted focus on the efficiency of basic social service delivery characterized this period. With a paradigm focusing on growth and the role of markets, a history of practice in which public spending far outstripped public revenues, and a deep concern about corruption and incompetence in the delivery of services, social policies were subordinated to the need for growth. In this increasingly dominant view, only through economic growth could countries afford to provide for social development expenditures.

Indeed, the 1980s were a very difficult decade for the social sectors-budgets for education, health, and public health were slashed, issues such as housing, nutrition, and urban and rural development simply fell off the agenda, and multiple investments at the project level survived only through mechanisms such as the social development funds that were adopted more for political reasons than economic ones. In some parts of the world, this was the "lost decade" not only in terms of growth but also in terms of advances in social development. The neoliberal paradigm, deeply suspicious of states, encouraged experimentation with alternative means of providing for social welfare through privatization, contracting out, assessing fees for services, and sponsoring NGO activities. Overall, this period witnessed a return to a social policy agenda that focused broadly on the basics in poor countries. The particular needs of poor people much less important in the neoliberal view, and often responses to such problems were channeled through specialized social adjustment programs. ${ }^{23}$

I.5. A Return to Incremental Agenda Expansion. The decade that was initiated by a world economic crisis in 1982 was notable for cutbacks in social welfare spending and a gradual deterioration in the quality and quantity of public services provided to citizens in many countries. Nevertheless, even as neoliberal thought and practice fundamentally altered the agenda of what needs to be done to stimulate development, a critique-based in part on observation of the impact of neoliberal policies on social provisioning - began to emerge by the late 1980s. Characterized by Tony Killick as A Reaction Too Far, the anti-statism of the neoliberal paradigm shift of the 1980s was attacked. ${ }^{24}$ While emerging reactions to "market fundamentalism" acknowledged that markets needed to be the primary movers of economic development, states needed to provide a series of institutions and services that would encourage markets to be effective and efficient. Law and order and property rights-long the basic neoliberal expectations about what states needed to do-expanded to include more than a focus on downsizing, deregulating, and privatizing; revised thinking began to encompass a positive role for the state in providing the governance necessary for economic growth to proceed.

Research on the experience of the East Asian "miracles" played an important role in the intellectual debate-some of these countries had very active and interventionist states that stimulated rather than constrained growth. ${ }^{25}$ In addition, the application of neoliberal shock therapy as Russia moved to a market economy without a set of appropriate institutions in place, increased the visibility of the "new institutional economics," a perspective emphasizing the importance of well-established rules of the game to the proper functioning of markets in economics, politics, and organizational behavior. $^{26}$ That Douglass North won the Nobel Prize for economics in 1991 for his 
work on institutional economics added to the critique about the over-zealousness with which the neoliberal paradigm was adopted and put into practice. ${ }^{27}$ The 1991 World Development Report included a chapter on the state, an important sign of the rehabilitation of a positive role for the state in mainstream discussions of development; the 1997 Report was focused on the state in development.

An important characteristic of the development discourse of the early and mid-1990s, therefore, was the increased awareness of the importance of effective public bureaucracies and stable institutions of governance for market-based development to proceed. It was not enough to "get the policies right;" an appropriate institutional infrastructure would be essential for generating investment and growth. Not surprisingly, early discussions focused on institutions that were considered directly relevant to the operation of markets - the judiciary, central banks, tax authorities, ministries of finance-but gradually, the idea of investment in human resources reemerged as part of the appropriate task of the state in the promotion of development. Nevertheless, throughout this period, development researchers and many practitioners emphasized the social provisioning would be largely a consequence of economic growth; as countries expanded their trade and investment policies and strengthened their institutions, they would grow and thus have increased resources to invest in social policies. ${ }^{28}$

Meanwhile, in political science, where intellectual disillusion with authoritarian regimes of various kinds had been growing, social policy acquired new importance. In part, social development returned as a more important ingredient of the development agenda because the "third wave" of democratization had brought a resurgence of democratic regimes and greater concern about whether such regimes could deliver benefits to citizens. $^{29}$ Politicians, encouraged by the programmatic or clientelistic commitments of their parties, faced the discipline of periodic elections with promises to expand social provisioning. The mobilization of voters, and even the legitimacy of democratic regimes, were important reasons why politicians needed to be more concerned with responsiveness. ${ }^{30}$ This encouraged a reinstatement of the importance of social investments as a critical obligation of the state.

Equally important in the 1990s, a strong “third sector” voice of non-governmental organizations and civil society groups emerged to attack neoliberal policies and the impact of the lost decade of social investment on citizens and on the poor in particular. This activist movement focused attention on increases in indices of poverty, the cost of ignoring social provisioning, the rights of citizens to a variety of services, and the human destruction caused by the cold hand of the market. During the 1990s, a plethora of real world voices pushed against the dominant paradigm and eventually helped force a reconsideration of the role of the state. Indeed, agenda expansion of the 1990s and 2000s owes much to the advocacy of various groups who promoted the importance of issues such as the environment, human rights, security, and human capabilities to social development. ${ }^{31}$ These voices were validated through research on human development and human capabilities, well presented in the annual Human Development Reports of the United Nations Development Programme. ${ }^{32}$ 
I.6. The Current Agenda-and its Ambiguities. By the 2000s, it is fair to say that mainstream development discourse had adopted a renewed appreciation of social policy in economic development, but one chastened by the experience of states that had grown too large, spent too much, and delivered too little in earlier periods. Yes, in a new and complex mainstream perspective, states needed to provide a range of social services-but these services needed to be efficiently provided; could be stimulated to be more effective and efficient through the private provision of some of them; should be decentralized to capture benefits from allocative efficiency, information on local preferences, and local demand for performance; and should be monitored for evidence of corruption, clientelism, and ineffectiveness. ${ }^{33}$ At the same time, the list of what needs to be done to ensure social development expanded noticeably. Research from the 1990s on indicated that poverty had increased under neoliberal policies, urban poverty was increasing, and income inequality was mounting. ${ }^{34}$ It was not difficult for development professionals to conclude that more needed to be done to address the problems faced by poor people. Issues such as social housing, nutrition, and rural development found their way back onto the social agenda of the 2000s.

Thus, after a decade of limiting social provisioning to essential public services and seeking means to simulate markets in their design and delivery, and a decade of rising intellectual concern and action about evidence of widespread poverty, the 2000s could be characterized by renewed agenda expansion, activities to enhance the capacity of the state to deliver essential services, and a renewed focus on the needs of poor people. ${ }^{35}$ Social policies were further distinguished from economic development and became identified with human rights and a range of services necessary to ensure the equitable expansion of human capabilities. ${ }^{36}$

At the same time, the neoliberal paradigm left behind important concerns about corruption and the effective delivery of social services. Building administrative capacity for social policy delivery, decentralizing service provision, as well as new experiments with conditional cash transfers as a way of generating demand were all aimed at strengthening the link between investments in social sector services and the payoff in terms of enhanced education, health, and, importantly, poverty alleviation. Demand for effective services could be generated by providing citizens with incentives to send their children to school and to ensure that citizens had regular preventive health care. The experience of countries such as Brazil and Mexico in the early development of ideas about cash transfers accorded well with a growing appreciation that it would be possible to improve services through demand generation and more direct means to reach poor people. $^{37}$

In the 2000s, then, important new ideas and practices-demand stimulation, efficient allocation of resources, decentralization of services, conditional cash transfers, microcredit to encourage access to markets and asset accumulation by the poor, social insurance for the poor, randomized experiments to discover what works, the idea of social inclusion and exclusion-joined on-going ideas about the social provisioning role of the state to generate new policies and new programs. ${ }^{38}$ The renewed attention to poverty alleviation, building on efforts from the 1990s, also expanded the range of social 
actions undertaken by states. Added to these trends, rapid globalization fed concerns about economic immigration in search of jobs, and the potential for rapid global spread of communicable diseases further underscored the return to social policy as an instrument of development. That scholars and practitioners increasingly argued that social policy was integral to the solution of global problems such as the climate change, energy security, international trade, security, governance, immigration, and other major issues further complicated thinking about social policy and development. Moreover, another level of complexity was added in a growing critique about the utility of international development assistance. $^{39}$

Thus, the agenda for social development was extremely broad at the outset of the 2010s, its relationship to economic development not universally agreed, and the concerns of advocates extremely diverse. This agenda was rich with demands, competing voices, experimentation, new ideas, divided interests, on-going criticism of mainstream thinking, and the legacies of prior thinking and acting about development. For researchers and practitioners alike, one question is inescapable: Where could we go from here?

\section{Where Could We Go from Here?}

In Section I of this paper, three questions underlay the assessment of the evolution of thinking and practice in social policy and poverty alleviation: What is the role of social policy in economic development? What is the appropriate role of the state in social policy provisioning? and, Should the focus of concern be poor countries or poor people? The ensuing and stylized view of shifting responses to these three questions suggested some conclusions that are relevant to the discussion of multilateral development coordination and coherence.

First, achieving an integration of social and economic policy requires a clear statement, currently lacking, in how social policy advances the development of countries. Experiences on the ground are diverse enough to make such a statement difficult to agree upon. Second, a renewed consensus on the role of the state in social policy must to be tempered by increased awareness that states differ in terms of their ability-and willingness - to take on tasks of development. Third, and related, because the poverty and social exclusion of people now takes center stage in concerns about policy, the trap of an ever increasing agenda is a real one that must be addressed. One important way to keep agendas within reason is to focus more on country-specific strategies and a clear sense of priorities. This section of the paper develops these three points.

II.1. Integrating Social and Economic Development Policy. As indicated in the previous section, social and economic development were integrated goals of early thinking about how countries could become wealthier. As experience and ideas changed, however, they tended to become separate foci and research and practice encouraged specialization and compartmentalization of thinking and practice. Currently, some are questioning this separation, as the focus of WESS2010 indicates. 
The challenges to a more holistic view of development are great: academic and applied specializations have grown up to support and increase specialization of focus; the macroeconomics of how countries fare in development are very difficult to integrate with the micro-focus of current research and practice in social policy and poverty alleviation; discussions of growth imperatives are difficult to combine with assertions about human rights; and the acknowledgement of complexity sits uneasily with grander integrating themes. In addition, the difficulty of reconceptualizing the integration of social and economic development is evident in the cases of a number of countries that have distinct experiences and whose development trajectories do not lead to easy compartmentalization as successes or failures. It is a challenge to draw clear lessons from their different trajectories.

II.1.1. Social Development in Costa Rica, Sri Lanka, China, and Kerala. Costa Rica, Sri Lanka, China, and Kerala state in India are four cases in which policy makers made significant commitments to social investments at early stages of development, focusing on a broad improvement of welfare as a foundation for future economic growth. Indeed, social indicators made impressive progress in each of them as their governments invested in broad policies for education, health, infrastructure for public health, and nutrition. In the 1960s, and with the exception of China, whose experience was largely rejected because of its basis in communist ideology and authoritarianism, these cases were often used to demonstrate the wisdom of broad commitment to social development and poverty alleviation and efforts at inclusive development. Key to their success in improved social conditions, it was argued, were leadership commitment to this goal and political organizations and ideologies that generated broad public support for it.

Yet Costa Rica, Sri Lanka, and Kerala were often referenced in the 1980s as examples of policy commitments that resulted in slow and unsustainable development; social policies and poverty alleviation, it was claimed, had been pursued without adequate attention to economic growth. Thus, while each of the three cases generated relative progress in social indicators, their economies did not demonstrate a clear trajectory of growth and the burden of financing social investment was seen as a factor in constraining growth. This evidence was used to argue that economic growth was an essential first step toward sustainable social investment.

More recently, perspectives on this experience have shifted again, at least in the case of Costa Rica and China. While Costa Rica has still not been successful in generating rapid growth, its experience in investing in human development-particularly education-is credited with its ability to take advantage of global technological and biotechnological advances to develop a range of industries and research activities that ensure it important niche markets in the world. The case of China, although not often viewed through the lens of the payoff to earlier social policy investment, is certainly an example of rapid and sustained economic growth that was, in part, supported by the ready availability of a literate and healthy labor force. Thus, that there might be a longer term pay-off to early investment in social development has been recently rediscovered in debates in development. 
II.1.2. Social Development in Brazil and South Africa. From the 1950s through the 1960s, Brazil and South Africa focused attention and investment primarily on generating rapid economic growth. Both were relatively successful and could show strong records of growth for sustained periods of time. Yet both countries were also frequently used examples of extensive inequality and poverty, attention to the health and education needs only of restricted elites, and growing evidence of gaps between the wealthy and the poor, in both cases - but particularly and deliberately in South Africa - exacerbated by very significant racial divides. In much discussion of poverty and development, even in the 1980s and 1990s, these countries were held up as evidence that a focus on economic growth could result in worsening conditions of social welfare for extremely large portions of the population,

More recently, however, Brazil and South Africa are credited with having made major progress toward more inclusive development. Indicators of health and education seem to support the wisdom of current policy initiatives to direct increased resources to the social sectors and both countries are in the forefront of discussions about policy innovation in social development. In particular, Brazil has become famous for its experiences with conditional cash transfers, and South Africa, despite many problems, has demonstrated results from very progressive policies for overcoming historical racial differences in health, education, and employment. This experience, then, supports a model of growth first with a subsequent focus on social investment, even while acknowledging significant costs of social inequality that must later be overcome.

\section{II.1.3. Social Development in Singapore, South Korea, Taiwan, and Malaysia.} Singapore, South Korea, and Taiwan—well known as East Asian Tigers—and Malaysia — a Little Tiger - are perhaps the best examples of countries that have been able to bring economic and social development policies into significant alignment. Early investment in broad national policies for education and health, combined with concern for equitable distribution of land in South Korea and Taiwan, were combined with clear national policies focused on generating rapid economic growth. While much recent analysis of their development success has focused on the trade orientation of their economic development policies, it is clear that these countries also established and maintained commitment to the broad provision of social policies and were able to improve the quality of social services as they progressed toward greater economic development, an extremely difficult achievement. A focus on equity in the cases of Singapore, Taiwan, and Malaysia was encouraged by political concerns about ethnic divisions.

The experiences of these countries are impressive, all the more so as they have been sustained for long periods of time. The lessons they provide for other countries are important. Yet these lessons need to be tempered with an understanding of the importance of country context in explaining development success. All four countries had strong national leadership that was important in defining a broad development strategy; Singapore, South Korea, and Taiwan embarked on these strategies in a relatively supportive international economic context; and each had relatively strong states vis-à-vis the power of domestic social and economic groups. They were thus in a strong position 
to set national policies, to experience early benefits from them, and to be able to sustain these choices over a significant period. All but South Korea faced significant challenges of internal conflict related to ethnic distinctions. For contemporary analysis of the role of social policy in development, these cases provide good examples of what might be achieved, but it is not at all clear that the conditions that allowed for the success of these four countries can be replicated elsewhere.

II.1.4. What Lessons? These case experiences create a conundrum in terms of being able to establish a clear statement of how social policy relates to economic development, particularly when contextual factors are considered. Thus, from these few examples, it is debatable if an obviously superior model for integration or sequencing of social and economic development is evident, at least one that is replicable. Lessons from history can be ambiguous, then. This suggests a possibility explored in the next part of this section - that a universal model of integrated social and economic development and poverty alleviation might not be particularly useful because states vary considerably in their needs and capacities.

II.2. The Role of the State in Social Policy. Although the issue of a model for integrating social and economic development more effectively remains a conundrum, the review of development thinking in Section I of this paper indicates that there is a consensus about the importance of the state in advancing development. The fall-out of neoliberal excesses in the 1980s and 1990s, as well as improved understanding of the role of institutions in development, in fact, have brought new respect for how states can advance development.

At the same time, development scholars and practitioners are newly and increasingly aware that states differ in terms of their capacities for developing and pursuing strategies for development and governments differ in their interest in doing so. Even while broad commitments to human development are increasingly stressed, the mechanisms about how individual countries are to achieve these goals are more subject to debate. ${ }^{40}$ As indicated above, the development successes of a number of East Asian countries were a result of strong, developmentalist states that made good decisions at opportune moments domestically and internationally; there is reasonable doubt, therefore, about the ability to replicate these conditions in many other countries. Equally, experiences of extremely low capacity, political incoherence, and on-going warfare have infused discussions of development with concerns about fragile states, failed states, displaced populations, and communal violence. ${ }^{41}$ Thus, increasingly, mainstream thinking has acknowledged more space for diverse approaches to social development, emphasizing that there is no one right solution for the distinct conditions of a variety of countries.

II.2.1. Assessing What Can Reasonably Be Expected from Counties. This perspective is a good basis for considering how development thinking and practice can advance in the area of social development: states are important to economic and social development yet states differ in their capacities. Development research and practice needs to make more of the new consensus around these two issues in advancing social policy and poverty alleviation goals. One of the most important advances that could be made is to be much 
more adept at aligning what is desirable with what is possible in terms of individual countries. By contextualizing development strategies, the activities taken on by states at different levels of capacity are more likely to be feasible and to be less overwhelming of existing capacity.

At a relatively simple level of analysis, for example, there are countries that have the capacity to take on complex tasks of development and to make considerable advances in social and economic welfare. Some such countries have states that can be considered "developmental," in the sense of states that have internal coherence, that have the capacity to select development strategies appropriate to time and conditions, that enjoy sustained political support for these choices, that have public bureaucracies able to take on such tasks effectively, and that can learn from their experiences as a basis for altering policies and strategies. Clearly, many of the East Asian countries would fall into this category. But there are also other countries that are capable of taking on quite complex tasks in the design and delivery of social policies and the alleviation of poverty, and that have shown good progress in doing this. Countries such as Mexico, Brazil, Chile, South Africa, Colombia, and some states in India may fit into this category.

Other countries — some in the Middle East, Ghana, Botswana, the Philippines, Peru, Uganda, Thailand, a number of states in India might be cases in point-have the capacity to develop and pursue less complex and more focused strategies, while still being able to make significant progress toward social development and poverty alleviation. These countries have the foundations for relatively coherent states and the capacity for planning and implementing a range of social and economic policies, although each faces difficulty in mobilizing political support for national strategies and policies and the organization and capacity of public organizations is far from optimal.

There are also countries whose capacities and context suggest that social and economic development are long up-hill struggles. African countries such as Burkina Faso and Tanzania and small countries such as Nicaragua and Honduras in Central America may be good examples of states that are weak and that have only limited capacity and political consensus for moving forward with any effective development strategy. For such countries, the selection of a few priority areas of state action, based on a rigorous examination of resources and capacities to act can help limit the potential for overwhelming existing capacities, increasing wasted resources, and contributing to alltoo-frequent policy failure.

And some countries may be close to stateless, with extremely limited capacities for embarking on any long-term strategy for development-Afghanistan, Haiti, the Central African Republic, the Democratic Republic of Congo, Somalia, and Yemen, for example. In such countries, the focus may need to be on interventions to establish minimum conditions of security and order, the establishment of legitimate state power, and the effective use of humanitarian assistance. Certainly, the ways in which these interventions are planned and achieved have important long-term consequences for how states emerge and develop the capacity to generate development, but it is also clear that efforts to ensure ambitious goals such as inclusive development are almost certain to fail when 
states have collapsed, are extremely fragile, or when they are in the rent by on-going violent conflict.

II.2.2 Assessing States as They Are. A simple point-states differ in their capacities to take on complex tasks of economic and social development-should be the basis for assessing the requirements of distinct kinds of strategies and policies and aligning them with the existing capacities of individual states. Developmental states exist in current practice. In many countries that cannot currently boast of these kinds of coherent and capable states, the ability to move toward them can be systematically obstructed by insisting on long lists of what must be done, by policy advice that is not assessed carefully for feasibility, and by a failure to consider not only capacities but also priorities for social and economic development. Thus, an important step toward the creation of more effective developmental states is a clear recognition of existing conditions and capacities. End goals - the creation of coherent and politically stable states-are important for visions - but these goals are not advanced by development strategies that attempt to take on all issues in contexts of limited capacity.

II.3. The Agenda Issue: People not Countries. Over time, thinking in the area of social development has increasingly privileged concern about the status of poor people over a more general concern about the status of poor countries. As a consequence of research and practice, the development community is extremely sensitive to the fact that social needs are great in developing countries and the range of vulnerabilities of poor people is extremely broad. Indeed, as indicated in Section I, as data, research, and reflection on practice have expanded, there has been a long term trend toward agenda expansion in social policy, punctuated, as we have seen, by a period of significant paradigm change. In particular, the growing importance of the idea of human development and the discussion of human rights and social policy indicates interest in increasing the extent to which poor people, in particular, can expand their capacities to live full and productive lives.

Thus, as we have seen, one consequence of the very valid concern with human development has been a long term trend toward agenda expansion in the social sectors, a trajectory that underscores the issues raised above about drawing distinctions among countries in terms of their abilities to take on complex tasks of development. A significant danger for many developing countries is, as suggested above, is the possibility of being overwhelmed by what needs to be done when the human and resource foundations for doing it are limited. ${ }^{42}$ Indeed, in promoting a comprehensive agenda, many international development agencies and advocacy organizations have acted to overload the fragile capacities of some states, and have contributed to policy failures when extensive expectations of moving in many directions at once are not met. ${ }^{43}$

Once people, not countries, have been acknowledged to be the appropriate goal of social development, it is difficult to limit agenda expansion. But the solution to this problem is not to abandon concerns for the welfare and rights of people. Instead, the agenda of what needs to be done needs to be organized much more around attention to issues of getting from here to there. In such a perspective, concern about the process of how states and 
countries get from here to there would be much more prominent. Process development and attention to priority setting might then replace simple statements of the end goals of development.

International development coherence and cooperation can help re-frame issues of social development through less aspirational and more realistic goal setting. For example, aligning international coherence with national coherence could be advanced by approaching country assessments not on the basis of needs-an approach that tends to expand agendas beyond the capacity of many countries to deliver-but on the basis of capacities for implementation. The international discourse can become more explicit in concerns about agenda expansion, setting priorities, and matching policies with the capacity to deliver. International agencies need to agree to commit resources to priority areas in specific countries - and to find ways to help countries make good choices about what those priority areas are. If this is taken as a measure of international coherence and cooperation, it is clear that approaches such as the PRSP process may actually contribute to agenda expansion and the destruction of fragile capacities that might have been better used had they been employed with a clear eye to feasibility.

An important role for international actors, then, is to find ways to encourage countries to take the most useful next steps toward greater development at any given time. In particular, this means that advances in coherence and cooperation at international levels need to be used to advance coherence at national levels-and that what coherence means will differ across countries. In this case, the assessment of policy content (what needs to be done to be developed) should not lead but follow assessments of capacities, priorities, and the need to focus limited resources.

\section{Coherence and Cooperation: How Effective a Tool?}

International actors_-primarily researchers and development agencies, but also international NGOs - are important in setting agendas in development and in influencing the role of social policy in development. Indeed, they have often been dominant actors in shaping and reshaping the discussion of what needs to be done for economic and social development to occur. Yet there is significant need for caution in expectations about how much international coherence and cooperation can achieve at country-specific levels. The influence of international actors is conditioned by how decisions are reached in national politics, and, even if there were greater international coherence and cooperation, the pull of domestic politics would still condition choices and results.

The politics of the policy process are complex and they differ across countries. ${ }^{44}$ Nevertheless, there are some general patterns that tend to characterize the development of new social policies and the alteration of old ones in a large number of countries. In particular, the dynamics of decision making in many developing countries tend to privilege executive leadership and the participation of technical experts, both domestic and international. In this context, the role of international development agencies can be extensive; these organizations often bring ideas and funding to the table, and both resources can influence outcomes of agenda setting, policy design, and decision making. 
At the same time, domestic actors tend to have increased capacity to constrain international influences when policies are negotiated with diverse interests. This characteristic is even more apparent during the implementation of social policy, when the capacity of domestic actors to influence the allocation of social policy resources and the distribution of services is extensive. ${ }^{45}$ Expectations about the consequences of greater international coherence and cooperation thus need to be viewed in terms of a politics of policy making and implementation.

III.1. Decision Style in Policy Making. In very general terms, policy making in developing countries tends to be more executive-focused, more insulated from public debate, and more centralized than similar activities in institutionalized Western democracies. ${ }^{46}$ Despite increased democratization and efforts to decentralize political power in recent years, decision making in many countries remains more top down than distributed among agencies, levels of government, and varieties of interests.

Executives are generally initiators and designers of policy. In many countries, long traditions of presidential leadership and centralized power tend to diminish the role of legislatures in the design, and often the negotiation, of public policies. While this dynamic is changing as democratic competition opens up a larger role for legislative political parties, a legacy of executive dominance of decision making and policy initiative remains important in a large number of countries. Poorly developed staffing, clientelism, and frequent electoral calendars may also limit the extent to which legislatures play important roles in the design and negotiation of policy contents. When policies become fragmented and projectized, the approval of legislators may even be avoided entirely.

In addition, and again in very general terms, interest groups and civic associations of many kinds often tend to be less fully organized and prolific in developing countries than in more developed ones, increasing the distance between government and the capacity of interest groups and citizens to be engaged in debates over the contents of policies as they are being designed. ${ }^{47}$ Similarly, political parties are often more clientelistic than they are programmatic, which tends to focus their actions and concerns more on the distribution of policy benefits during implementation than on broad ends of policies as they are being designed. Think tanks, actors that often play key roles in policy debates in a number of developed countries, are often incipient actors in developing countries, less present and less knowledgeable about the policy process. The same can be true of the media. Professional associations and unions of providers - very important actors in determining the outcome of policies — can be left out of the loop in the policy design process, and end up having the most capacity to influence policy during implementation.

As a consequence of such conditions, policy decision making in many countries is relatively insulated. In practice, this tradition tends to increase the role of technical and academic expertise in the design of social policy. In brief, presidents or ministers tend to indicate policy preferences and appoint technical teams-also known as design or reform teams - to develop proposals in line with these preferences, and only when proposals are relatively well developed will they be presented to cabinets, ruling juntas, legislators, or the press. ${ }^{48}$ 
In turn, the composition of the technical teams and their role as gatekeepers in discussions and negotiation of policy proposals tend to be important factors in the politics of policy design. ${ }^{49}$ Their disciplinary training will often have a significant impact on how policies are designed; economists and engineers may have very different ways of thinking about education or health policy and approaching their design than educators or doctors, for example. Similarly, technical teams tend to make important determinations about who should be invited to the table to discuss alternatives in the content of new policies, thus serving as important gatekeepers of the range of perspectives and interests consulted. ${ }^{50}$ The range can be broad or narrow; the important feature of the discussions, however, is the extent to which design teams play this important—and political-gatekeeping role. Moreover, their political role may be enhanced by factors such as their commitment to the political leaders who appointed them.

Moreover, when decision making is relatively closed, issues of capacity may not be well integrated into thinking about the delivery of services. The real world test of what is feasible may be overlooked as policy designers and decision makers devise elaborate mechanisms to allocate resources and to monitor services. The importance of training may be overlooked, and overly optimistic scenarios about logistics may make their way into expectations about how policy will be implemented. In the real world, the failure of timely delivery of textbooks, chalk, medicine, and medical supplies has undermined a surprising number of good ideas. ${ }^{51}$ Thus, a dynamic of executive centeredness can mean that social policy development is less attuned to characteristics of administrative and political capacity actually to deliver the policies. The relatively strong influence of international assistance agencies early in the process of agenda setting and policy design can thus even contribute to the potential for policy failure.

III.2. Who's at the Table When Important Decisions Are Made? Metaphorically, the content of policies is determined by a set of actors "at the table" when important decisions are made. Obviously, policy making is an on-going and iterative process, and there are not one but several tables. Nevertheless, the table metaphor helps illuminate the political economy of what gets chosen as policy and who is consulted in this process. The question of who's at the table is critical to what interests and perspectives have a say in policy choice and which tend to be excluded.

As indicated above, technical and academic experts tend to be important actors at the table, and they may have particular political, personal, and disciplinary commitments that affect their perspectives. International actors with technical expertise also tend to be very present at the table, and to have perspectives on what needs to be done to resolve social policy challenges. Frequently, they are the voice of mainstream development thinking as it is translated into plans for action. They also represent the perspectives and resources of particular agencies, and their understanding of the development discourse may be important in terms of their willingness to commit resources to a particular problem. Their influence at the table therefore tends to be enhanced by implicit or explicit offers of funding to promote particular approaches to social problems. ${ }^{52}$ 
In addition, public officials from relevant ministries are generally at the table, either as part of the technical team or as representatives of the administrative roles they play in policy development and implementation. Often, social policy is extremely fragmented in terms of organizational responsibilities, so this means that there may often be several competing ministries, agencies, and programs at the table at the same time. In addition, some ministries may also represent the interests of particular professional or workers' groups, such as doctors, teachers, or lower level officials. This is so because in some countries it is not unusual for those who represent particular organized interests to be regularly appointed to leadership and other positions within ministries; in the most extreme cases, ministries may even be “colonized” by powerful unions or professional associations. $^{53}$

Many relevant interest groups are less regularly at the table, even though they are often powerful in domestic politics. For example, health professionals and paraprofessionals, teachers' unions, and associations of engineers and architects, and others involved in the delivery of services represent large numbers of stakeholders and they are often associated with particular political parties. Teachers, health professionals, administrators and others also tend to represent middle-class or aspiring middle-class interests, and they tend to be influential in local communities in election campaigns and other politically relevant activities. But the extent to which they are at the table tends to reflect the extent to which these associations are part of a support structure for governing parties or whether they represent a mainstream or a marginal opposition. They are almost always consulted if they are part of a governing party or coalition, at times consulted if they are prominent in the opposition, and rarely consulted if they are considered part of a "fringe" political opposition. $^{54}$

The extent to which domestic and international NGOs are represented in policy decision making is often limited. In general, governments tend to be skeptical of such organizations and the interests they represent, thus discouraging the extent to which they are invited to the table or are part of design negotiations. Such organizations, in turn, are often skeptical of the objectives of governments and may even be reluctant to be officially part of policy discussions. ${ }^{55}$ At times, if they are at the table, it may only be at the insistence of international development agencies. Moreover many potentially influential actors - such as organizations representing the interests of better off sectors of the population-have limited interest in social policies because they have increasingly opted for private providers of services.

Domestic and international economic interests can also be very relevant actors for social policy - construction firms and their associations, pharmaceutical groups, manufacturers and distributors of equipment for hospitals and schools, and so on-but these associations are rarely consulted or formally invited to the table. Similarly, representatives of local and regional governments are often expected to play important roles in the delivery of social services, particularly in eras such as the current one in which decentralization is encouraged. Rarely, however, are they formally represented in policy decision making. Finally, it is extremely rare for those representing the direct beneficiaries of social 
policies - parents and patients, for example — to be present when policies are being decided upon. ${ }^{56}$

An important characteristic of social policy making in many countries, then, is that those who are most important to the delivery of social policies are not always on board when new policy initiatives are presented to a legislature or when they are announced as new policy. They may have little information about the policy initiatives and little understanding of their purpose. These characteristics of policy making can add to the tentativeness and contentiousness of policy implementation, and to the potential for redefinition, slippage, and sabotage when policy is being put in practice.

III.3. Implementing New Policies. Social policies are usually administratively complex and resource- and action-intensive in terms of how they are delivered. As a consequence, social policies are particularly prone to implementation challenges. Yet, most policy analysis focuses on the design and approval of policy and assumes that subsequent action is primarily a matter of administrative engineering. From a political perspective, however, the process of implementation often places social policy objectives in great jeopardy. Indeed, implementation is a highly political process in most countries, a process that can reshape, scuttle, redirect, destroy, or otherwise alter the intent and impact of policy. ${ }^{57}$

As we have seen, for example, a relatively closed decision making process can translate into the absence of many of those with a stake in the outcome from discussions of design and the negotiation of policy contents. As a consequence, the considerable power of these actors, important among whom are administrators and service providers, tends then to become focused on the implementation of policy and a variety of forms of resistance to change can be employed. Foot-dragging, misinterpretation of the intent of policy, failure to act, stumbling on technical details, and other such quiet measures of resistance can characterize administrative responses to new social policy initiatives.

Service providers can similarly slow and distort implementation through failures to act. Organized providers also have the capacity to employ more public measures of resistance, such as strikes or the threat of strikes, public protests, and the use of their privileged positions in society to influence public opinion. Clearly, resistance to new social policies is likely to be directed at policies that impose burdens on administrators and providers or that alter their power, a point returned to below.

In addition, social policies tend to provide divisible benefits - schools and clinics, for example, or admission to school or a visit to a doctor or nurse, a vaccination, a school textbook, allocation of public housing, etc. In what tends to be a highly competitive market for such benefits in poor countries, clientelistic political parties often flourish. Of course, not all parties cohere around the distribution of benefits to their constituencies or gather force from voters by promising and delivering individual and community-based "pork," but it is certainly a common practice in many countries-developed and developing. Under such conditions, the allocation of social policy services can be distorted to certain individuals, certain communities, certain regions, or partisans of 
particular parties - all to the detriment of those not part of these constituencies. In practice, policy resources may not end up in the hands of their intended beneficiaries, or beneficiaries may differ depending on electoral outcomes.

Moreover, many of those who are critical actors in the process of policy development lose their capacity to be influential during policy implementation. Thus, after critical decisions have been made about the content of new policies and after formal approval has been gained for them, designers and policy makers at the center tend to lose control over the destiny of these policies. They have other issues to contend with, their influence over the administrative apparatus may be shallow, or they may be voted out of office, replaced by others with distinct agendas and concerns.

Often, then, power shifts downward in a political system during implementation. Particularly where social service provision is decentralized, and where policy making has been relatively closed and top-down, actors such as governors, mayors, NGOs, local community interlocutors, and others may not necessarily have been on board when the policy was designed. If service providers have not been consulted, they may also have significant incentives to use their resources to distort implementation. The fate of policies may now be much more in their hands. Their perspectives and orientations become paramount in determining whether and how well a policy will be implemented.

In contrast, and despite conscious efforts to avoid this result, international actors lose much of their influence during implementation. Their capacity to intervene in administrative processes, to deal directly with political parties, unions of providers, or local governments is severely constrained. Consequently, they have a difficult time exerting much influence over the destiny of policy initiatives once these initiatives have been designed and approved. ${ }^{58}$

III.4. Social Policies Are Often Contentious. The contents of social and poverty alleviation policies are important because they determine how different actors will align in support or opposition to such initiatives, their perspectives significantly shaped by the distribution of anticipated benefits and costs if new policy is adopted. Policy proposals are inherently political, even when developed in the academy in technically sophisticated ways. In particular, some social policies - those that are primarily focused on the expansion of access - are more likely to enjoy the support of diverse actors than are those that are primarily focused on improvements in the quality of services. ${ }^{59}$ In practice, whatever the ideas behind social policy interventions, there tends to be a political bias in favor of more services rather than higher quality ones. ${ }^{60}$

The following table indicates differences in the political dynamics of policies that enhance access and those focused on quality enhancement. Basically, access-oriented policies increase the benefits offered to a variety of potential constituencies-more jobs for administrators and service providers, more contracts for school and clinic builders and for textbook and medicine suppliers, more members and dues for unions when more teachers or nurses are hired, more tangible benefits for politicians to claim credit for, and more physical evidence of government presence for voters to reward. As a consequence 
of these broadly evident benefits, important interests - administrators, contractors, unions, politicians, parties, and voters tend to be supportive of policies that increase access to services.

\section{Table 1}

The Politics of Access and Quality Reforms: A Comparison

\begin{tabular}{|c|c|c|}
\hline & $\begin{array}{c}\text { Access } \\
\text { Reforms }\end{array}$ & Quality-Enhancing Reforms \\
\hline $\begin{array}{l}\text { Typical actions to carry out } \\
\text { such reforms }\end{array}$ & $\begin{array}{ll}\text { - } & \text { Build infrastructure } \\
\text { - } & \text { Expand bureaucracies } \\
\text { - } & \text { Increase budgets } \\
\text { - } & \text { Hire administrators } \\
\text { - } & \text { Hire service providers } \\
\text { - } & \text { Buy equipment }\end{array}$ & $\begin{array}{ll}\text { - } & \text { Improve management } \\
\text { - } & \text { Increase efficiency } \\
\text { - } & \text { Alter rules/behavior of } \\
\text { - } & \text { personnel } \\
\text { - } & \text { Improve accountability } \\
\text { - } & \text { Strengthen local control }\end{array}$ \\
\hline $\begin{array}{l}\text { Typical political implications of } \\
\text { such reforms }\end{array}$ & \begin{tabular}{ll}
\multicolumn{2}{l}{ Creation of benefits: } \\
- & Jobs \\
- & Construction and \\
& provisioning contracts \\
- & Increased budgets \\
- & Increased power for \\
& ministries and managers
\end{tabular} & $\begin{array}{l}\text { Imposition of costs: } \\
\text { - } \quad \text { Loss of jobs } \\
\text { - } \quad \text { Loss of decision making } \\
\text { - } \quad \text { power for some } \\
\quad \text { New demands, expectations, } \\
\text { responsibilities for others }\end{array}$ \\
\hline $\begin{array}{l}\text { Typical political response to } \\
\text { such reforms }\end{array}$ & 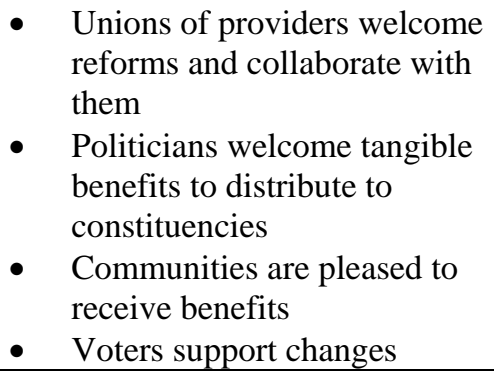 & 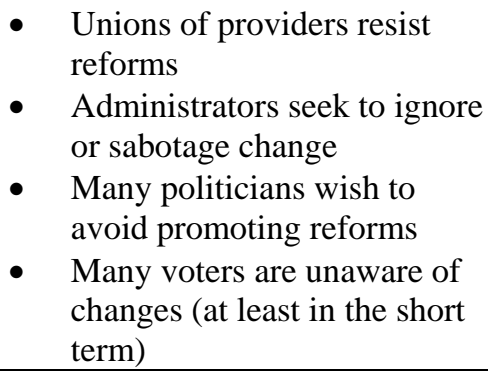 \\
\hline $\begin{array}{l}\text { Typical long-term political } \\
\text { consequences of these political } \\
\text { dynamics }\end{array}$ & $\begin{array}{l}\text { - Unions of providers grow } \\
\text { larger and gain greater } \\
\text { political voice } \\
\text { Politicians and political } \\
\text { parties become focused on } \\
\text { the distribution of tangible } \\
\text { and divisible benefits } \\
\text { Communities and voters are } \\
\text { responsive to clientelistic } \\
\text { practices }\end{array}$ & $\begin{array}{ll}\text { - } & \text { Unions of providers are } \\
\text { significant veto players in all } \\
\text { social policy reforms } \\
\text { - Administrators lack } \\
\text { incentives to address } \\
\text { performance issues } \\
\text { Access reforms are default } \\
\text { policy choices for politicians } \\
\text { and political parties } \\
\text { Middle class voters exit to } \\
\text { private markets for social } \\
\text { provisioning }\end{array}$ \\
\hline
\end{tabular}

Source: Elaborated from Grindle 2004:6.

This perspective alters significantly in policies whose main import is to improve the quality of services. Managerial “tightening up," emphasis on efficiency, reallocation of authority, higher expectations about performance and accountability, new mechanisms of oversight and rewards and penalties related to salaries and career trajectories, fewer resources for infrastructure, greater engagement of citizens in monitoring-these are all aspects of quality enhancement that tend to impose burdens on those most important to 
the delivery of services. Administrators are likely to resist loss of authority, jobs, and resources. Providers are likely to resist new standards of performance and accountability and politicians may not wish to incur their disapproval. In addition, quality enhancement is less tangible and immediate than physical infrastructure or supplies of medicines and textbooks, so politicians find such policies less attractive to support and voters may not be aware of gradual improvements in quality.

Moreover, when social policies have expanded rapidly but have lagged in quality, middle class beneficiaries often exit to private markets for social services, thus diminishing the potential influence of a social sector that has historically been extremely important in developed countries in demanding better quality services. And, for a variety of reasons, it tends to be more difficult for poorer constituencies to demand effective service delivery - they tend to be less organized and less articulate politically. Not surprisingly, then, building more schools or clinics often becomes a default position for governments committed to social provisioning, and the cycle of improved access but poor quality may thus be reinforced. ${ }^{61}$

III.5. The Responsibilities of Constrained Power. This political perspective on the content of social policy also implies significant constraints on international actors promoting policy coherence and coordination for enhanced social wellbeing. Even when there is a high degree of international coherence and cooperation, domestic politics related to the allocation of costs and benefits limit the extent of international influence. Ultimately, what international agencies can achieve is constrained by the characteristics and political implications of the policies they choose to promote.

This political perspective also emphasizes that the strongest cards that international actors have to play are those related to the ideas and resources put behind the pursuit of these ideas in policy design. Indeed, international cooperation agencies have invested heavily in research on development, both in-house and contracted-out to academic institutions and researchers, and have been important consumers of new insights developed within academic disciplines - particularly economics - and the dissemination of these ideas through scholarly publications, training, and advising. In particular, the role of publications such as the World Bank's World Development Report, and the United Nations Development Programme's Human Development Report have codified the findings of mainstream research, drawn lessons from that research, and engaged in important debates that question the implications of research and experience.

Considerations of how to achieve greater coherence and cooperation present the potential for strengthening the hands of the players that hold important cards of ideas and resources. But it is important also that increased capacity to speak with one voice also increases the accountability that international actors assume for the ideas they adopt. In the search for policy coherence and cooperation, then, international actors have an obligation to be cautious in advocating new ideas and relying overmuch on the results of academic research that have not faced a real world test. Many familiar with the past 60 years of development thinking and the role of international actors can identify a strong tendency for new ideas to become fads or even magic bullets for development, promoted 
through exaggerated promises of the benefits of "participation," "basic needs," "getting the policies right," "markets,” "decentralization,” "good governance,” and other such concepts.

Greater international coherence and cooperation can be a dangerous goal if they are coupled with a strong belief in recipes for development, unexamined best practices, or one best way success stories. Section I of this paper was clear in indicating that ideas change over time and "getting it right" is always a work in progress. Moreover, "getting it wrong” can be responsible for significant human and economic costs, such as when market-oriented policies are promoted and adopted without due concern for their limitations, the institutional underpinnings they require, or the lives of those who are harmed by them. Similarly, assertions that there are best practices and success stories that can be emulated without attention to contextual factors can be a significant chimera in development. ${ }^{62}$ It is also a very seductive chimera, because it promises good results in a world fraught with uncertainty, frustration, failure, and the need for very long time horizons.

Development remains a protracted, frustrating, difficult, and often elusive process and countries differ fundamentally in their resources, capacities, opportunities, and histories, causing them to have diverse responses to policy choices and practice. International actors are particularly influential in the realm of ideas about what needs to be done. Thus, if greater coherence and cooperation is achieved, it comes with a special obligation to keep ideas within reason, to ensure a certain humility in the dissemination and popularization of new approaches to social policies, and to exercise caution in championing perspectives that have not had time to face the test of practice. Thus, one important-and counterintuitive-implication for more effective coherence and cooperation is that international cooperation agencies must remain sensitive to the evolution and diversity of ideas that are considered in the promotion of social development.

\section{New Paradigms and Old Realities}

It is possible that this paper, written as a background note for WESS2010, will be unwelcome to the authors of that report. At a basic level, it calls into question the idea that generating a new paradigm for development will provide helpful responses to the wide range of economic and social challenges that a very broad range of countries currently face. By indicating the way in which ideas about development alter and change and are a consequence of the interaction of research and practice, it suggests that the ability to come up with overarching responses to development challenges is limited. Big ideas have been important in the evolution of development thinking and practice, but their history also demonstrates a need to understand development as a process in which learning and change occur. While today's big idea does not necessarily become tomorrow's albatross, movement toward international coherence and cooperation should incorporate means for learning from practice, flexibility, and adaptation to changing circumstances. 
Similarly, this paper suggests that because there is currently greater awareness of the diversity and contextual realities of developing countries, big ideas about development may not address the particular needs of countries with different capacities to take action, or different degrees of interest in doing so. Instead, the paper suggests the need for more focus on the link between the current capacities of individual countries and the choice of policies they can feasibly embark upon. The paper, then, indicates the need for more rigorous examination of specific cases and responses to social policy issues that are particularly relevant to particular cases. The results of such an approach will have an impact on policy - careful assessment of what might work in particular contexts is an important factor in policy innovation, as the experience with conditional cash transfers suggests.

This paper also raises some unwelcome thoughts about international development coherence and cooperation. Achieving these worthy goals could possibly result in less vibrant debates about how development occurs, even in the potential for notions about development to become frozen in time, as can happen when large numbers of actors take on similar perspectives. When international actors are more able to speak with one voice, particularly about what needs to be done, the potential for their increased influence is counterbalanced by increased risk that the policy advice and guidance offered might be inappropriate or not fully adjusted to national or local realities. The paper also suggests that even with greater coherence and cooperation, the capacity to affect social development policy outcomes is constrained by domestic political processes, interactions, and conflicts.

In several ways, then, this paper presents a contrarian view to expectations about WESS2010. Throughout, it suggests that choices about social policy do not reflect an easy translation of ideas into practice, that ideas are often not well-grounded in the complexities of reality, and that international cooperation agencies cannot always exert effective influence in the pursuit of social policy within countries. These are likely to be unpopular conclusions - and with good reason.

They do, however, offer a different perspective on what might be the big ideas that guide social development policy and poverty alleviation. For example, a bold departure from practice might be to advocate for greater attention to the complex and contextually specific interplay of ideas, actors, institutions, and process as ways to encourage social development progress. A useful role for international actors would then be to develop the frameworks and approaches that help fit aspirations to realities on the ground. Likewise, such an approach can set the basis for much greater capacity to assess priorities and ground strategies in country capabilities. This is largely unexplored territory. Thus, to balance the extraordinary amount of effort that is put into research and practice on long lists of what needs to be done, international coherence and cooperation could help generate clearer thinking about country specific questions like: What should be done as a next step and what are effective means to take this step? This would be an important contribution to development thinking and to the effectiveness of international actors in the promotion of social development and poverty alleviation. The big idea, then, would frame a discussion of next steps. 
In a similar vein, the assessment of the role of social policies in economic development might be restated in very concrete terms: given the situation in a particular country with regard to social development and the opportunities available for economic development, how might these goals be brought closer together? Rather than trying to define the optimal role for the state in social policy and poverty alleviation, why not develop tools for considering the most effective ways to employ limited, modest, or more extensive state capacity and to assess opportunities for other mechanisms for social developmentrelying on NGOs or the private sector, for example-as a consequence of this analysis? The big idea, then, would be to frame a discussion of next steps toward a better reality.

For many, of course, this may not be an exciting way of proceeding to frame a debate in development. Yet, reframing questions in these equally difficult but perhaps less ambitious ways offers an opportunity to bring ideas and possibilities in the real world into greater alignment. Unfortunately but inevitably, this world is characterized by imperfect information, changing circumstance, frustrated initiatives, and differential power and influence. Searches for international coherence and cooperation need to be fully embedded in an appreciation of this difficult reality. 


\section{Notes}

${ }^{1}$ For a statement of this issue, see "Towards a New Development Paradigm? Coherence in Development Policy and International Cooperation.” Notes from a workshop to discuss the World Economic and Social Survey 2010, New York, November 16, 2009.

${ }^{2}$ In this paper, the discussion focuses on "mainstream" ideas and practice related to development, reflecting discussions and actions that characterize dominant theories in economic and political development, and the perspectives that are regularly presented by major international development organizations in publications such as the World Development Report and the Human Development Report. At all times and in all places, such ideas and practices are challenged and disputed from a number of perspectives. In addition, there are often disputes within the dominant discourse about issues of development. Challenges to the mainstream and debates within it encourage reflection and revision of this discourse over time. In the stylized and brief discussion in this paper, the nuances characterizing these disputes and discussions are largely absent. An extensive review of on-going debates in the field of development economics is found in James M. Cypher and James L. Dietz, The Process of Economic Development. London: Routledge (2009, Third Edition). For a discussion of political science literature, see Howard Handelman, The Challenge of Third World Development. Upper Saddle River, NJ: Prentice Hall (2008, Fifth Edition).

${ }^{3}$ Leading examples of this early generation of development economics are: W.Arthur Lewis, "Economic Development with Unlimited Supply of Labour,” Manchester School of Social and Economic Studies. Vol. 22, no. 2 (1954):139-191; Paul Rosenstein-Rodan, Paul, "The Theory of the Big Push,” in Gerald Meier, ed., Leading Issues in Economic Development. Oxford: Oxford University Press (1976, originally published in 1961); Walt Rostow, The Stages of Economic Growth: A Non-Communist Manifesto. Cambridge: Cambridge University Press (1960); Ragnar Nurkse, Problems of Capitalist Formation in Underdeveloped Countries. New York: Oxford University Press (1953); Gunnar Myrdal, Economic Theory and Underdeveloped Regions. London: Duckworth (1957); Albert O. Hirschman, The Strategy of Economic Development. New Haven, CT: Yale University Press (1958). See also Gerald Meier and Dudley Seers, eds., Pioneers in Development. Oxford: Oxford University Press (2004). As indicated in note 2 above, this paper does not discuss the important debates within early discussions of development.

${ }^{4}$ The literature on development is extensive and has been benefited from insights of political science, sociology, anthropology, and history as well as economics. This paper focuses primarily on issues of concern to economists and political scientists.

${ }^{5}$ An important work in this vein is Alexander Gerschenkron, Economic Backwardness in Historical Perspective. Cambridge, MA: Harvard Belknap (1962). The work of Raúl Prebisch and Hans Singer was extremely influential in this discussion and provided important theoretical foundations for import substituting industrialization and later, for a radical critique of early theories of development. See Raúl Prebisch, The Economic Development of Latin America and Its Principal Problems. New York: United Nations 
(1950); and Hans Singer, "The Distribution of Gains between Investing and Borrowing Countries,” American Economic Review. Vol. 40 (May 1950): 473-485.

${ }^{6}$ As a consequence, development assistance of the 1950s and early 1960s encouraged the generation of 5-year development plans.

${ }^{7}$ See Cypher and Dietz (2009): Chapter 5 (note 2 above).

${ }^{8}$ See, for an example, Theodore Schultz, “Capital Formation by Education,” Journal of Political Economy. Vol. 68 (1960): 511-83. See also Cypher and Dietz (2009): Chapter 12 (note 2 above). In human capital formation, education is granted preeminence as a target for social investment.

${ }^{9}$ For examples, see David Apter, The Politics of Modernization. Chicago, IL: University of Chicago Press (1965); and Gabriel Almond and G. Bingham Powell, Comparative Politics: A Developmental Approach. Boston, MA: Little, Brown (1965)

${ }^{10}$ An important work in this vein was Samuel Huntington, Political Order in Changing Societies. New Haven, CT: Yale University Press (1968).

${ }^{11}$ For an example, see Theodore W. Schultz, Transforming Traditional Agriculture. Chicago, IL: University of Chicago Press (1964).

12 In particular, see Michael Lipton, Why Poor People Stay Poor: Urban Bias in World Development. London: Temple Smith (1977).

${ }^{13}$ An early statement of dependency theory is Paul Baran, The Political Economy of Growth. New York: Monthly Review Press (1957). See also André Gunder Frank, Capitalism and Underdevelopment. New York: Monthly Review Press (1967); Samir Amin, Unequal Development. New York: Monthly Review Press (1976). Foundations for this critique are found in the work of Raúl Prebisch and Hans Singer (note 5 above). See also Fernando Henrique Cardoso and Enzo Faletto, Dependency and Development in Latin America. Berkeley: University of California Press (1979); Teotonio Dos Santos, "The Structure of Dependence," American Economic Review, Vol. 60 (May 1970); and Peter Evans, Dependent Development. Princeton, N.J.: Princeton University Press (1979).

${ }^{14}$ See, for example, Montek Ahluwalia, “Inequality, Poverty, and Development,” Journal of Development Economics, Vol. 3, no. 4 (December 1976): 307-342. For an overview, see Gary Fields, Poverty, Inequality, and Development. New York: Cambridge University Press (1980).

${ }^{15}$ Literature on inequality and women in development from the 1970s and 1980s is well presented in Irene Tinker, ed., Persistent Inequalities: Women and World Devleopment. Oxford: Oxford University Press (1990). 
${ }^{16}$ Early work of Amartya Sen was important in this discussion, as were the data produced by U.N. agencies. For a current view, see Wim Naudé, Amelia Santos-Paulino, and Mark McGillivray, Vulnerability in Developing Countries. Tokyo: United Nations University Press (2009).

${ }^{17}$ For early work reflecting this rethinking, see Anne O. Krueger, "The Political Economy of the Rent-Seeking Society,” American Economic Review. Vol. 64 (June 1974): 291-303. See also Jagdish Bagwati, “Directly Unproductive, Profit-Seeking (DUP) Activities,” Journal of Political Economy. Vol. 90 (1982): 988-1002; David C. Colander, ed., Neoclassical Political Economy: The Analysis of Rent-Seeking and DUP Activities. Cambridge, MA: Ballinger Publishing Co (1984); T.N. Srinivasan, "Neoclassical Political Economy: The State and Economic Development," Politics and Society. Vol. 17, no. 2 (1985): 115-162; World Bank, Towards Sustained Development in Sub-Saharan Africa. Washington, D.C.: The World Bank (1984). For a critique of this literature, see Merilee S. Grindle, "The New Political Economy: Positive Economics and Negative Politics,” in Gerald M. Meier, ed., Politics and Policy Making in Developing Countries: Perspectives on the New Political Economy. San Francisco: ICS Press (1991).

${ }^{18}$ See, for examples, Donald Rothchild and Naomi Chazan, eds., The Precarious Balance: State and Society in Africa. Boulder, CO: Westview Press (1988); David Collier, ed., The New Authoritarianism in Latin America. Princeton, N.J.: Princeton University Press (1979); Richard Sandbrook, The Politics of Africa's Economic Stagnation. Cambridge: Cambridge University Press (1985); Robert Bates, Markets and States in Tropical Africa. Berkeley: University of California Press (1981); James S. Wunsch and Dele Olowu, The Failure of the Centralized State: Institutions and SelfGovernance in Africa. Boulder, CO: Westview (1990); Patrick Chabal, ed., Political Domination in Africa. Cambridge: Cambridge University Press (1986).

${ }^{19}$ An important statement of the reaction against the state in the mainstream discourse is found in World Bank, Towards Sustained Development in Sub-Saharan Africa. Washington, D.C.: The World Bank (1984).

${ }^{20}$ Among well-known works on democratization are a series of four volumes edited by Guillermo O’Donnel1, Philippe Schmitter, and Laurence Whitehead and published by The Johns Hopkins University Press. Volume 4 provides an overview of conclusions: Guillermo O’Donnell and Philippe Schmitter, Transitions from Authoritarian Rule: Tentative Conclusions about Uncertain Democracies. Baltimore, MD: The Johns Hopkins University Press (1986).

${ }^{21}$ The term "Washington Consensus" has been coined to characterize the neoliberal approach to development. See especially, John Williamson, Latin American Readjustment: How Much Has Happened? Washington, D.C.: Institute for International Economics (1989). 
${ }^{22}$ See especially the citations in note 17 above. In addition, the World Bank's World Development Reports from the 1980s provided an on-going critique of the role of the state in development.

${ }^{23}$ See Giovanni Andrea Cornia, Richard Jolly, and Frances Stewart, eds., Adjustment with a Human Face. New York: Oxford University Press (1987); K. Subbarao, Anhiruddha Bonnerjee, Jeanine Braithwaite, Soniya Carvalho, Kene Ezemenari, Carol Graham, and Alan Thompson, Safety Net Programs and Poverty Reduction: Lessons fro Cross-Country Experience. Washington, D.C.: World Bank (1997).

${ }^{24}$ Tony Killick, A Reaction Too Far: Economic Theory and the Role of the State in Developing Countries. London: Overseas Development Institute (1989). See also, Peter Evans, Dietrich Reuschemeyer, and Theda Skochpol, eds., Bringing the State Back In. New York: Cambridge University Press (1985). An important addition to the discussion of social policy and the role of the state came in 1990 with the first publication of the United Nations Development Programme's Human Development Report, which advocated strongly for a comprehensive view of development based on an index of human development.

${ }^{25}$ Influential work includes Alice Amsden, Asia's Next Giant: South Korea and Late Industrialization. New York: Oxford University Press (1989); Robert Wade, Governing the Market: Economic Theory and the Role of Government in East Asian Industrialization. Princeton, N.J.: Princeton University Press (1990); World Bank, The East Asian Miracle: Economic Growth and Public Policy. New York: Oxford University Press (1993); Peter Evans, Embedded Autonomy: States and Industrial Transformation. Princeton, N.J.: Princeton University Press (1995). Moreover, exogenous growth models in economics reintroduced the notion of human capital investment as a contributing factor to economic development.

${ }^{26}$ See, for example, John Harris, Janet Hunter, and Colin M. Lewis, The New Institutional Economics and Third World Development. London: Routledge (1995).

${ }^{27}$ See especially Douglass North, Institutions, Institutional Change, and Economic Performance. New York: Cambridge University Press (1990). In the same tradition, see Oliver E. Williamson, “The Institutions of Governance,” The American Economic Review, Vol. 88, no. 2 (May 1998) and, by the same author, "The Institutions and Governance of Economic Development and Reform," Proceedings of the World Bank Annual Conference on Development Economics (1994). For empirical work in this tradition, see Lee J. Alson, Trainn Eggertsson, and Douglass C. North, eds., Empirical Studies in Institutional Change. Cambridge: Cambridge University Press (1996).

${ }^{28}$ Discussions of endogenous growth during this period dissented from this position, arguing that investment in education in particular was an essential element in growth. Evidence from the East Asian "miracle" economies were often used to bolster this argument. 
${ }^{29}$ On the transitions to democratic regimes, see the work cited in note 20 above; Samuel Huntington, The Third Wave: Democratization in the Late Twentieth Century. Norman: OK: University of Oklahoma Press (1991); Arend Lipjhart and Carlos Waisman, eds. Institutional Design in New Democracies. Boulder, CO: Westview Press (1996).

${ }^{30}$ See, for example, Merilee S. Grindle, Audacious Reforms: Institutional Invention and Democracy in Latin America. Baltimore, MD: The Johns Hopkins University Press (2000).

${ }^{31}$ A good source on this experience is Margaret Keck and Kathryn Sikkink, Activists Beyond Borders: Advocacy Networks in International Politics. Ithaca, NY: Cornell University Press (1998).

${ }^{32}$ In addition to the Human Development Reports, see Mahbub ul Haq, "The Human Devleopment Paradigm.” In Sakiko Fukuda-Parr and A.K. Shiva Kumar, eds., Readings in Human Development: Concepts, Measures and Policies for a Development Paradigm. New York: Oxford University Press (2003): 17-21.

${ }^{33}$ For an example of an institutionalist approach to social service provision, see William D. Savedoff, ed., Organization Matters: Agency Problems in Health and Education in Latin America. Washington, D.C.: Inter-American Development Bank (1998).

${ }^{34}$ This literature emerged in the 1990s and continued to be an important topic of research into the 2000s. It considered issues of economic and political inequality and their relationship to poverty and poverty alleviation. See, for examples, Barbara Stallings and Wilson Peres, Growth, Employment and Equity: The Impact of Economic Reforms in Latin America and the Caribbean. Washington, D.C.: Brookings Institution and the Economic Commission on Latin America and the Caribbean (2000); Nancy Birdsall, David Ross, and Richard Sabot. "Inequality and Growth Reconsidered: Lessons from East Asia,” World Bank Economic Review, Vol. 9, no. 3 (1995); UNDP, Human Development Report 2005. New York: Oxford University Press, (2005); Peter P. Houtzager and Mick Moore, eds., Changing Paths: International Development and the New Politics of Inclusion. Ann Arbor: University of Michigan Press (2003); Barbara Harriss-White, "Destitution and the Poverty of its Politics-With Special Reference to South Asia," World Development, Vol. 33, no.6 (2005): 881-891; Sam Hickey, "The Politics of Staying Poor: Exploring the Political Space for Poverty Reduction in Uganda," World Development, Vol. 33, no. 6 (2005): 995-1009. Kaushik Basu, "Globalization, Poverty, and Inequality: What is the Relationship? What Can Be Done?” World Development, Vol. 34, no. 9 (2006):1361-1373

${ }^{35}$ For a discussion of the development of this emphasis, see Merilee S. Grindle, "The Social Agenda and the Politics of Reform in Latin America," in Joseph S. Tulchin and Allison M. Garland, eds., Social Development in Latin America: The Politics of Reform. Boulder, CO: Lynne Rienner Publishers (2000): 17-52; See also Joan M. Nelson and 
collaborators, Fragile Coalitions: The Politics of Economic Adjustment. New Brunswick, N.J.: Transaction Books (1989); Abhijit V. Banerjee and Esther Duflo, "The Economic Lives of the Poor,” Journal of Economic Perspectives. Vol. 21, no. 1 (Winter 2007): 141167; Nancy Birdsall, Carol Graham, and Richard H. Sabot, eds., Beyond Tradeoffs: Market Reform and Equitable Growth in Latin America. Washington, D.C.: InterAmerican Development Bank and Brookings Institution (1998).

36 The work of Amartya Sen is seminal in the discussion of human capabilities as an approach to development. One statement of this is found in Amartya Sen, Development as Freedom. New York: Random House (1999).

${ }^{37}$ For a review of conditional cash transfer programs and issues of social inclusion, see Bénédicte de la Brière and Laura B. Rawlings, Examining Conditional Cash Transfer Programs: A Role for Increased Social Inclusion? Washington, D.C.: World Bank Institute (2006).

${ }^{38}$ See, for example, Nora Lustig, ed., Shielding the Poor: Social Protection in the Developing World. Washington, D.C.: Brookings Institution Press and the InterAmerican Development Bank (2001).

39 See Deborah Braütigan, Aid Dependence and Governance. Stockholm: Almqvist and Wiksell International (2000); S. Feeny, N. Hermes, and R. Lensink, "Controversies Over the Impact of Development Aid: It Works; It Doesn't; It Can, But That Depends,” Journal of International Development, Vol. 18, no. 7 (2006): 1031-1050. On international development cooperation and the social sectors in particular, see Joan M. Nelson, Reforming Health and Education: The World Bank, the IDB, and Complex Institutional Change. Washington, D.C.: Overseas Development Council (1999).

${ }^{40}$ See, for example, World Bank, World Development Report 2004.

${ }^{41}$ See, for example, Louise Anderson, Bjorn Moller, and Finn Stepputat, Fragile States and Insecure People? Violence, Security, and Statehood in the Twenty-First Century. New York: Palgrave (2007).

42 The issue of long agendas and how they tend to grow is addressed in Merilee S. Grindle, “Good Enough Governance: Poverty Reduction and Reform in Developing Countries,” Governance: An International Journal of Public Policy and Administration, Vol. 17, no. 4 (October 2004): 525-548.

${ }^{43}$ Mick Moore, Amab Acharya, and Ana Fuzzo de Lima, “Aid Proliferation: How Responsible Are the Donors?” IDS Working Paper 214 (2004)

${ }^{44}$ Analysts often adopt a stylized concept of the policy process that involves agenda setting, policy formulation, and implementation. In reality, of course, this process is far from linear. It is complex and interactive, with many feedback loops and opportunities 
for reversal and reaction, making it difficult to separate these phases in practice.

Nevertheless, I believe it is useful to disentangle some of the complexities of the process by isolating analytically some of the dynamics that tend to occur at various points in the policy process.

${ }^{45}$ On the issue how process can alter the roles of political actors, see James A. Trostle, Johannes U. Somerfeld, and Jonathon L. Simon, "Strengthening Human Resource Capacity in Developing Countries: Who Are the Actors? What Are Their Actions?” in Merilee S. Grindle, ed., Getting Good Government: Capacity Building in the Public Sectors of Developing Countries. Cambridge, MA: Harvard University Press (1997); Soonman Kwon and Michael R. Reich, "The Changing Process and Politics of Health Policy in Korea.” Harvard Center for Population and Development Studies, Harvard University, Working Paper Series, Vol. 13, no. 10 (October 2003).

${ }^{46}$ There is an extensive literature on policy making in developing countries, much of it focused on the politics of policy reform. See, for examples, Merilee S. Grindle, Challenging the State: Crisis and Innovation in Latin America and Africa. New York: Cambridge University Press (1996); Merilee S. Grindle, Despite the Odds: The Contentious Politics of Education Reform. Princeton, N.J.: Princeton University Press (2004); Grindle, 2000 (note 32 above); Merilee S. Grindle and John W. Thomas, Public Choices and Policy Change: The Political Economy of Reform in Developing Countries. Baltimore, MD: The Johns Hopkins University Press (1991); John Williamson, ed., The Political Economy of Policy Reform. Washington, D.C.: Institute for International Economics (1994); Nelson and collaborators, 1989 (note 35 above); Stephan Haggard and Robert R. Kaufman, eds., The Politics of Economic Adjustment. Princeton, N.J.: Princeton University Press (1992); Robert H. Bates and Anne O. Krueger, eds., Political and Economic Interactions in Economic Policy Reform. Cambridge, MA: Basil Blackwell (1993); Joan M. Nelson, ed., Economic Crisis and Policy Choice: The Politics of Adjustment in the Third World. Princeton, N.J.: Princeton University Press (1990).

${ }^{47}$ Grindle and Thomas, 1991: Chapter 3 (note 46 above).

${ }^{48}$ Evidence for this is found throughout the work cited in note 46 above. In addition, see Miguel Angel Centeno, Democracy Within Reason: Technocratic Revolution in Mexico. University Park, PA: Pennsylvania State University Press (1994); Jorge Domínguez, ed., Technopols: Freeing Politics and Markets in Latin America in the 1990s. University Park: PA: Pennsylvania State University Press (1997); James Malloy, "Policy Analysis, Public Policy and Regime Structure in Latin America,” Governance: An International Journal of Public Policy and Administration. Vol. 2, no. 3 (1989): 315-338.

49 This is an observation that has come out of the literature on policy reform cited in note 46 above.

${ }^{50}$ Case study examples of this are found in Grindle, 2004 (note 46 above). 
${ }^{51}$ See the case studies in Merilee S. Grindle, Politics and Policy Implementation in the Third World. Princeton, N.J.: Princeton University Press (1980).

${ }^{52}$ The literature cited in note 46 above provides multiple insights into the influence of international actors on policy reform.

${ }^{53}$ See case study examples in Grindle, 2004 (note 46 above).

${ }^{54}$ The way these professional associations and unions are organized also affects their ability to be influential during policy design initiatives. Most commonly, the organization of health professionals is more fragmented than the organization of teachers' unions. In many countries, there are doctors' associations, nurses' associations, and paraprofessional, administrative, and custodial unions, while in education, teachers and educational administrators are often represented by one or very few large organizations. The organization and the political affiliation of these associations and unions is important because they affect the strength of the organization in representing interests, the extent to which they stand together or are divided over their interests, and the extent to which they are unified behind or within particular political parties.

${ }^{55}$ See, for example, Alan Fowler, "The Role of NGOs in Changing State-Society Relations, Development Policy Review, Vol. 9, no. 1 (March 1991): 53-84.

${ }^{56}$ On this and the previous point, see case study examples in Grindle, 2004 (note 46 above)

${ }^{57}$ There are, of course, a multitude of reasons why policies go awry during implementation, and not all of them are a result of politics. Yet, among many factors indicating that putting policies in practice is not an automatic result of policy approval nor simply a matter of good administration or best practices, political aspects of implementation are important in determining the fate of social policies on the ground. See Grindle 1980 (note 51 above) and Grindle and Thomas, 1991: Chapter 6 (note 46 above).

${ }^{58}$ At times, and in response to this loss of influence, international actors have sought to circumvent problems of weak institutions, low capacity, inappropriate incentives, and corruption by setting up project implementation units in ministries, units with strict oversight of the use of resources and monitoring of progress. Officials hired to be part of these units are often committed advocates of the policy in question, may have relatively high levels of expertise, and often receive salaries that are substantially higher than those of regular officials in the ministries they are attached to. The short term benefits of such units may be more effective implementation, at least for the life of a policy or program, but the long term consequences are usually resentful ministry officials who are not part of these units, a failure to build broader capacity and commitment to the policy, and a failure to institutionalize the program or policy. Such units tend to increase the number of "losers" in policy change. 
59 The argument here and in the following paragraphs is taken from Grindle 2004 (note 46 above).

${ }^{60}$ Ideally, of course, social policies should seek to enhance both the quantity and the quality of social services, such as, for example, when more children are able to go to school and enjoy a better education than was available in the past. In practice, however, there is a tendency for access-enhancing policies to outpace quality-assurance. From an administrative perspective, it is usually easier to construct new schools than it is to train and reward teachers more effectively; it is easier to appoint more nurses than it is to train them well; it is easier to build a new clinic than to ensure that patients are treated with respect and appropriate medications, etc. Certainly, access enhancing policies can be resource intensive and administratively complex, but from administrative and political perspectives, quality enhancement tends to be more difficult. From both viewpoints, access tends to be more rapidly accomplished than quality.

${ }^{61}$ Political constraints associated with generating higher quality services can also encourage the tendency to projectize social policies; efforts to alter administration, incentives, and structures of power may become pilot projects, for example, or aspects of additional initiatives rather than replacements for outmoded or "exhausted" approaches.

62 This has been referred to as "getting to Denmark" in recent development discussions. For a discussion, see Matt Andrews, "The Good Governance Agenda: Beyond Indicators Without Theory." Oxford Development Studies, Vol. 36, no. 4 (December 2008): 379407. 